the past seventeen years, particularly in the premature babies, but I am anxious that the difficulties, which are many for a mother in straitened circumstances, should not be unnecessarily increased, and the confidence undermined in the National dried milk. Cheapness has a snowballing effect to the good on the general economy of the family.-I am, etc.,

Edinburgh.

E. V. KuensSBerg.

\section{Dangers of Cigarette-smoking}

SIR,- It is not my wish to detract in any way from the report of the Medical Research Council (Journal, June 29, p. 1523) or the efforts of the Government to reduce the undoubted excessive and harmful smoking of a large part of the population; but having experienced nearly 30 years of mixed general practice, it seems to me that several questions require careful thought and even more careful answer.

In the last year I have had four patients die of " carcinoma of the lung," two males and two females. The two males both smoked, the one who died in his 80th year to excess, the other only moderately. One of the females had never smoked; the other had smoked to excess, and, although she was diagnosed in hospital as a primary lung cancer, at necropsy less than six months later she had a carcinoma of the stomach involving the whole of the posterior wall of the organ which must have existed for at least 18 months before her first chest symptoms, and was the undoubted cause of the thoracic secondaries. We are living in an $x$-ray age, but do let us be quite sure of our facts. Primary and secondary thoracic growths frequently look much the same on $x$-ray, and not all carcinomata of the body of the stomach are spotted on $x$-ray if the state of this organ is in fact questioned. I feel very strongly that statistics of the seriousness of those in mind can only be of real value when upheld by competent necropsy findings. Deaths from carcinoma of the lung and carcinoma of the stomach have many similarities. It is my belief that many of the diagnoses were not and still are not quite as accurate as we would wish to have them.-I am, etc., Wokingham

RalPh Rose.

\section{Cigarette Advertisements}

SIR,-In its leading article of June $\mathbf{3 0}$ the Observer states: "Many young people start smoking because it strikes them as a normal adult habit: we should do all we can to make it appear to them a bad and unnecessary habit." Whatever one thinks about action regarding adult smoking, most people who have read the recent reports will agree with the Observer.

In this connexion might $I$ as an advertising man-and one who owes a great debt to medical skill-make a suggestion? One of the factors persuading young people to smoke is of course advertising; and any publicity by the Ministry of Health on the findings of the Medical Research Council is likely to be more muted than its commercial counterpart, and will probably reach only the more thoughtful section of the community. For some years press and advertising alike have accepted a voluntary " code of standards" and have refused all advertising for many formerly accepted patent medicines, now thought to be harmful or to make dubious claims. Similarly, advertising for any type of treatment for a number of diseases is excluded from the press. There would seem to be an even stronger case for refusing publicity to products which cause avoidable disease, and I suggest that the medical profession uses its great influence to have the " code of standards" extended to include tobacco among the list of unacceptable advertising.

We in this country rightly dislike all limitation of freedom but if in fact there is a choice between the freedom of the cigarette manufacturer to persuade and of a young man or woman to be healthy, I believe the press (and commercial television) will recognize its responsibilities-even if a little tardily in some quarters.-I am, etc.,

Hatch End, Middx.

Harold Sumption.

\section{Giving Up Smoking ?}

SIR,- Some of my colleagues might be interested in a method of giving up cigarette-smoking which has proved successful and more or less painless both personally and to quite a large number of patients.

It should be borne in mind that there are three problems to be overcome, the drug addiction, the habit, and the psychological factor. The approach to the first problem is as follows. The addiction must be reduced, and so the smoker must be switched at once to a good filter-tip cigarette. At the commencement, this will cause some discomfort because so much of his drug is strained off by the filter-tip, and he must be warned not to increase his usual daily number of cigarettes. After 8 to 10 weeks' smoking of filter tips, he will already have lost a good deal of his craving and then it is much easier to reduce the number smoked until about five a day has been reached. This number can be kept up for another two to three weeks, and by the end of this time he has so little addiction left that it will be easy to cease the five at one "go." The next problem is, of course, the habit, and this is just as difficult, but I have found that eating a sweet at the normal time that one would smoke works well; holding a cigarette-holder empty in the mouth ; and, finally, that great solace to mankind-chewing gum. The psychological or emotional aspect was very tricky with several people until I had an inspiration and told people to call them "cancerettes." When your moral courage is failing and you surreptitiously creep through the house to find that packet, the thought that they are cancerettes produces the same effect as the letters V.D. used to do to another and older vice. Try the system and see it work.-I am, etc.,

Staines, Middx

Henry Bergh.

\section{Polyneuritis and Illness in Cats}

SiR,-Dr. A. M. G. Campbell has written to you about three cases of acute polyneuritis with raised protein in the cerebrospinal fluid associated with an acute illness of a cat in the house of a patient (Journal, May 18, p. 1183).

In March I had a patient under my care suffering from the Landry-Guillain-Barré syndrome. Three months before the illness started she had a kitten suffering from "cat influenza," of which there was an epidemic in the district in which the patient lives. Both the patient and the kitten have since completely recovered. The association here may also be coincidental, but I agree with Dr. Campbell that further investigations may be helpful in elucidating the aetiology of some of the forms of polyneuritis.-I am, etc.,

Harrogate.

T. G. ReAH.

\section{Diabetes Mellitus with Acute Polyneuritis}

SIR,-The communication of Dr. J. Wedgwood (Journal, June 8, p. 1346) prompts me to report a case seen at the Central Middlesex Hospital.

The patient, a woman of 62 , developed a sore throat, nasal catarrh, and a slight cough. Five days later she noticed difficulty in walking and two days later weakness of her hands, so that by the tenth day she was unable to get out of bed or feed herself. She also noticed "pins and needles" in her feet and hands when they were touched-this coincided with the onset of weakness in each limb. Previous medical history showed nothing of note. She had had three children, each weighing less than $10 \mathrm{lb}$. $(4.5 \mathrm{~kg}$.) at birth. There was no family history of diabetes mellitus.

Physical examination on admission revealed no abnormality in the cranial nerves. There was gross weakness of the limbs and trunk, in the legs maximal in the proximal muscles, and in the arms in the distal. The tendon jerks and abdominals were absent, plantar responses flexor. There was no objective sensory loss. Cardiovascular and respiratory systems were normal. Blood pressure was $150 / 90$. The significant lumbar puncture findings were:-On admission : protein $-75 \mathrm{mg} . \%$, globulin-slight excess, cells-6 R.B.C. per cu.mm. ; one week later: protein-70 mg.\%, globulin- 
very slight excess, cells-3 W.B.C., 1 R.B.C. per cu.mm.; three weeks later: protein-55 mg. $\%$, globulin-no excess, cells-none. Other findings were: haemoglobin-15.1 g. \%, total W.B.C. $-7,000$ per cu.mm., E.S.R. $4 \mathrm{~mm}$. in one hour, both red and white cells appeared normal; the urine contained no albumin, sugar, red cells, casts, porphyrins, or porphobilinogen ; $x$-ray of chest showed no abnormality in heart or lungs; blood and C.S.F. W.R. were negative; Paul-Bunnell test was negative. The only significant finding was a glucose tolerance test, which showed values (capillary blood) of $150 \mathrm{mg}$. \% fasting and 230, 260, 220, and $130 \mathrm{mg} . \%$ at half-hourly intervals after $50 \mathrm{~g}$. glucose by mouth. The test was repeated two weeks later and the results were 120 , $197,235,240,165$. In each case glycosuria occurred only in the last hour of the test. The condition of the patient improved slowly from the time of her admission. No new symptoms or signs appeared, though at times she had a persistent fever of $99^{\circ} \mathrm{F}$. $\left(37.2^{\circ} \mathrm{C}\right.$.). When discharged six weeks later she was able to walk alone and use her arms but still had considerable residual weakness.

The features in this case atypical of the Guillain-Barré syndrome are the absence of cranial nerve involvement and only a slight rise in the C.S.F. protein. The respiratory illness at the onset, the distribution of the weakness, and the predominance of motor signs are more characteristic of it. Reitman and Rothschild ${ }^{1}$ state that the Guillain-Barré syndrome has been seen in diabetics, but do not say whether it is seen more than in non-diabetics. In that the patient showed no objective sensory loss she resembled the cases of Garland $^{2}$ and Garland and Taverner. ${ }^{3}$ She differed, however, because of the sudden onset, rapid progression, and symmetry of the weakness, spontaneous recovery, and the complete absence of pain.

The finding of Haymaker and Kernohan ${ }^{4}$ of C.S.F. blood sugar of over $80 \mathrm{mg}$. \% in 7 out of 15 fatal cases of LandryGuillain-Barré syndrome (with a maximum figure of 182 mg. \%) may be of significance. None of these cases was stated to have diabetes. The conclusion which may perhaps be shown from these findings is that in cases of acute polyneuritis the investigation of glucose metabolism may be of value.

I thank Dr. R. J. Porter for permission to publish this case.-I am, etc.,

London, N.W.10.

REFERENCES

R. S. KOCEN.

4 Reitman, N., and Rothschild, K., Ann. intern. Med., 1950, 32, 923. 2 Garland, H., British Medical Journal, 1955, 2, 1287.

3 - and Taverner, D., ibid., 1953, $1,1405$.

Haymaker, W., and Kernohan, J. W., Medicine (Baltimore), 1949, 28. 59.

\section{First Aid}

SIR,-I submit that Sir Zachary Cope's review of Dr. R. A. Mustard's Fundamentals of First Aid" (Journal, June 8 , p. 1348) was far more merciful than the book deserved. Most will agree that the tourniquet is best forgotten and that antiseptics are best left out of wounds; many will be surprised that pressure points are not to be taught, though the arguments for the omission have some superficial logic. Yet I have known at least three lives saved by the use of pressure points, where other means of haemorrhage control would probably have failed. Dr. Mustard's book does not explain how his local pressure technique is to be used where severe bleeding comes from a fracture site.

Some frightening items to be noted in the book are :p. 59 : a firm bandage round the popliteal fossa ; pp. 59, $62,65,67$ : clear-cut advice to use traction on a fractured limb, by pulling firmly to straighten the broken bone; $p$. 79 : after (correctly) advising copious water washing to the chemical burn the author then advises applying baking soda or vinegar (amounts or strength not detailed) as neutralizing agent. It is commendable to try to teach first aid by simplification, but this attempt has failed. One paragraph from it headed "How to Give Fluid to a Child" must be quoted in full (p. 96) :

If the child refuses to drink copiously, wrap him in a blanket to pin down his arms or legs, pinch his nostrils, and pour the diluting fluid down his throat when he opens his mouth to breathe.

This terrible manœuvre, which would efficiently flood the trachea, is accompanied by a picture as near incredible as the text itself.-I am, etc.

Cambridge.

A. S. Playfair.

1 Mustard, R. A., Fundamentals of First Aid, 1955. Toronto.

\section{The Forgotten Thomas Splint}

SIR,- - I am disturbed to find that practically all the ambulance authorities-i.e., county ambulance services, St. John, and also, I understand, the National Hospital Reserve firstaid teams-are advising the use of long Liston splints for first-aid treatment of fractured femurs.

As long ago as 1916, during the first world war, Sir Robert Jones introduced the Thomas splint in the military services and showed convincingly that by its use mortality from fractured femurs could be dramatically lowered. In the second world war the Thomas splint was again widely used by all military services. In peacetime, however, these lessons appear to be forgotten and we have gone back to the long Liston splint which does little to immobilize the fracture, nothing to ease the pain, and cannot hope to prevent the onset of shock. Admittedly such casualties usually reach hospital within a very short time, but if they arrive with a well-applied Thomas splint on it makes examination in the casualty department much easier, transport to the $x$-ray department much easier, and the final transport to the ward less shocking to the patient.

I hope that by bringing this matter to your notice those responsible for the ambulance services may again provide Thomas splints and have their efficient application taught.I am, etc.,

Windsor.

G. P. Arden.

\section{Post-maturity}

SIR,-Professor F. J. Browne's paper (Journal, April 13, p. 851) has been commented upon critically by two different authors, Professor D. Baird and Mr. W. G. Mills (Journal, May 4, p. 1061). A biochemical study of newborn infants which we are doing ${ }^{1}$ supports Professor Browne's opinion that prolongation of pregnancy per se is not so dangerous and does not call for induction of labour.

The opinion, advocated by Walker ${ }^{2}$ and supported by MacKay, ${ }^{3}$ that the oxygen saturation falls with increasing gestation time is certainly not always valid. MacKinney et al. ${ }^{4}$ in a study of 594 infants in Buffalo found no support of Walker's thesis. In 202 cases with spontaneous uncomplicated delivery studied by us the following results were obtained (Table I).

TABLE I.-Umbilical Oxygen Saturation (Per Cent.) After Varying

\begin{tabular}{ll|l|l|l|l|l|l}
\hline Gestation Time in Weeks & 38 & 39 & 40 & 41 & 42 & 43 \\
\hline $\begin{array}{l}\text { Vein } \\
\text { No. of observations }\end{array}$ &. & $\begin{array}{l}61 \cdot 8 \\
20\end{array}$ & $\begin{array}{l}62 \cdot 9 \\
28\end{array}$ & $\begin{array}{l}61 \cdot 3 \\
39\end{array}$ & $\begin{array}{l}62 \cdot 6 \\
52\end{array}$ & $\begin{array}{l}60 \cdot 4 \\
33\end{array}$ & $\begin{array}{l}64 \cdot 5 \\
30\end{array}$ \\
\hline $\begin{array}{l}\text { Artery } \\
\text { No. of observations }\end{array}$ &. & $30 \cdot 6$ & $\begin{array}{l}39 \cdot 7 \\
\text { 16 }\end{array}$ & $\begin{array}{l}36 \cdot 4 \\
26\end{array}$ & $\begin{array}{l}34 \cdot 6 \\
42\end{array}$ & $\begin{array}{l}33 \cdot 0 \\
27\end{array}$ & $\begin{array}{l}30 \cdot 4 \\
25\end{array}$ \\
\hline
\end{tabular}

TABLE II.-Umbilical Oxygen Saturation (Per Cent.) at Varying

\begin{tabular}{cc|c|c|c|c}
\multicolumn{5}{c|}{ Degrees of Dysmaturity } \\
\hline \multicolumn{1}{c|}{ Stage of Dysmaturity } & $0-1$ & 1 & 2 & Normal \\
\hline Vein $\ldots$ &.. & $58 \cdot 6$ & $56 \cdot 9$ & $51 \cdot 1$ & $63 \cdot 7$ \\
No. of observations &.. & 35 & 59 & 12 & 104 \\
\hline $\begin{array}{l}\text { Artery } \\
\text { No. of observations }\end{array}$ &.. & $34 \cdot 7$ & $34 \cdot 6$ & $24 \cdot 3$ & $38 \cdot 7$ \\
\hline
\end{tabular}

If, however, the infants, not the duration of pregnancy, are studied a different picture will be seen (Table II). The infants have been classified as normal or dysmature as described by Ballantyne," Bossi," Bäcker," and Runge. ${ }^{8}$ The dysmature infants have then been grouped according to the stages described by Clifford.' As the word post-maturity is 